\title{
GRUNDTVIG OG TEATRET ENDNU ENGANG
}

Supplerende bemærkninger til Grundtvig-Studier 1950, s. 100-102.

\section{Af Steen Johansen.}

I sit skrift »Nikolaj Frederik Severin Grundtvig, et løst Udkast« (egl. et lidt udvidet særtryk af et afsnit af J. Kr. Madsens i 1872 udgivne beretning om Grundtvigs jordefærd og det kirkelige vennemøde samme aar) fortæller Frederik Barfod følgende paa s. 13: »Ogsaa med Sten Blicher gjorde (Grundtvig) Bekjendtskab, og de spillede stundom Komedie sammen i Borups Selskab«. Denne henvisning til Borups Selskab har hverken teaterhistorikeren Robert Neiiendam i sin afhandling eller undertegnede i bemærkningerne dertil (i Grundtvig-Studier 1950, $100 \mathrm{ff}$.) været opmærksom paa. Barfod henlægger dog fejlagtigt komediespillet til tiden omkring 1808, men paa s. 60 i samme skrift retter han det paa følgende maade: „I Kjøbenhavn mødtes de (St. St. Blicher og Grundtvig) atter 1803-04 i et dramatisk Selskab, og nu var det, de spillede Komedie sammen. Iblandt andet spillede Grundtvig Kudsken i »Gulddaasen «, og, saa vidt han tresindstyve Aar senere kunde mindes, blev der ogsaa engang opført en Komedie, som han selv havde skrevet«. Heller ikke oplysningen om, at Gr. spillede i »Gulddaasen«, er omtalt hos Neiiendam eller undertegnede; derimod er oplysningen om opførelsen af den af Gr. selv forfattede komedie »Brevet« velkendt fra Gr.s dagbøger, se Gr.s Udv. Skr. I, 33 f., $44 \mathrm{f}$.

Spørgsmaalet er nu, om vi ad anden vej kan faa disse oplysninger af Barfod bekræftet. »Borups Selskab《 var den sædvanlige betegnelse paa »Det dramatisk-litteraire Selskab«, stiftet 1780 . Om dets indretning og interessante og langvarige virksomhed (ledet af Rahbek) kan læses i Julius Clausens afhandling »Borups Selskab《 i »Museum《 1892 II, $341 \mathrm{ff}$. samt i Kaj Nielsen: Den store teatergalskab, 1953, $52 \mathrm{ff}$. Vi skal derfor ikke her fordybe os videre i denne side af sagen, men for det første bemærke, at hverken Grundtvigs eller Blichers navne forekommer i den i 1830 udsendte trykte fortegnelse over samtlige medlemmer siden selskabets stiftelse, hvori vi forøvrigt finder anført en lang rakke af datidens kendte personligheder. Blandt dem, der paa en eller anden maade stod Gr. nær dengang eller senere, kan nævnes: Gr.s tre fætre Henrik Steffens, Oluf Bang og Balthasar Bang, endvidere brødrene O. H. og J. P. Mynster, Oehlenschläger, Thorvaldsen, Cl. Pavels. Men antallet af medlemmer, ca. 6-700 i de 61 aar, selskabet bestod, giver ikke det rette indtryk af dets meget omfattende virksomhed. Et studium af de bevarede protokoller (i Ny kgl. Saml. 769r, fol.) viser, at tilskuer-medlemmer, gæstemedlemmer og lgn. ikke er medregnet, og det virkelige medlemstal maa have 
været langt højere. I en af protokollerne finder man under 4. nov. 1802, at en student Blicker er foreslaaet optaget som tilskuer. Dette er sikkert forfatteren, hvis navn man ogsaa i den samtidige universitetsmatrikel finder stavet paa denne maade. Han har altsaa deltaget aktivt uden at være egentlig betalende, fast medlem. Og noget lignende maa da ogsaa have været tilfældet med Grundtvig, hvis navn man forgæves søger efter. Samme protokol oplyser nu, at selskabet den 7. dec. 1803 opførte »Gulddaasen« (saavidt det kan ses overhovedet kun denne ene gang), men der meddeles desværre intet om de rollehavende. Grundtvig tog sin embedseksamen i oktober 1803, og af hans dagbog ser vi, at han den 29. okt. rejste hjem til Udby (Udv. Skr. I 45). Den 3. dec. ophorte han at fore dagbog for resten af dette aar. (Her er ikke tale om lakune p. gr. af bortkomne blade ell. lign.). Vi er da lige vidt m. h. t. bekræftelse, og heller ikke Blichers egne erindringer eller andre oplysninger om Bl.s ungdom kan opklare spørgsmaalet om begges medvirken i »Gulddaasen«. Men vi erfarer altsaa, at Blicher og Gr. har kendt eller i hvert fald sandsynligvis har kendt hinanden som studenter; forøvrigt har de i deres studentertid efter alt at dømme ogsaa truffet hinanden i Gundslev præstegaard paa Falster, se Lauritz Foss' erindringer i Personalhist. Tidsskr. 1882, 374; ogsaa antydet af Fr. Barfod i førnævnte skrift s. 60.

Naar jeg i mine bemærkninger 1950 skrev, at »efter at Gr. var blevet teologisk kandidat i oktober 1803, er rimeligvis hans forbindelse med selskabet (Thalia) ophørt af sig selv«, saa gælder altsaa disse ord kun nævnte selskab, men ikke teaterlivet. Efter at have spillet med i sin egen komedie »Brevet《 d. 11. sept. 1803 har han ca. tre maaneder efter $\mathrm{i}$ et andet teaterselskab spillet kusken Jochums lille, men djærve rolle i Olufsens prægtige komedie »Gulddaasen $\ll$. Ind imellem har han saa i oktober taget attestats med første karakter. 